\title{
Pengembangan Aplikasi Android Penghimpun Data Ekonomi Nasional Berbasis Crowdsourcing
}

\author{
Indra Azimia1, Aulia Azimi ${ }^{\mathrm{b} 2}$ \\ aProgram Studi Teknik Informatika, Fakultas IImu Terapan, Telkom University \\ 1indraazimi@tass.telkomuniversity.ac.id \\ bProgram Studi Ekonomi Islam, Fakultas Syariah dan Ekonomi Islam, IAIN Pontianak \\ 2auliaazimi@yahoo.co.id
}

\begin{abstract}
Abstrak
Keputusan yang tepat di bidang ekonomi nasional hanya dapat diperoleh dengan adanya data ekonomi nasional yang berkualitas. Sayangnya, proses pengumpulan data yang benar, akurat dan lengkap secara nasional tersebut masih mahal dan membutuhkan waktu lama. Oleh karena itu, penelitian ini menawarkan metode crowdsourcing sebagai metode alternatif menuju proses pengumpulan data nasional yang berbiaya murah dan bersifat dinamis. Dengan studi kasus pengumpulan data harga komoditas pokok secara nasional, metode ini terbukti dapat memberdayakan masyarakat umum sebagai pemilik data untuk melaporkan sendiri data harga komoditas di daerahnya melalui aplikasi Android yang disediakan secara gratis di Google Play Store. Penelitian ini dilakukan selama setahun, dari 2 Januari sampai 31 Desember 2015. Di akhir masa penelitian, tercatat 7.442 orang telah berpartisipasi secara aktif dengan distribusi yang merata di seluruh propinsi di Indonesia. Jumlah pengguna baru mencapai 34 orang per hari dengan data masuk mencapai lebih dari 400 data per hari, dan terus meningkat.
\end{abstract}

Kata kunci: Android, crowdsourcing, pengumpulan data, data ekonomi nasional.

\begin{abstract}
The right decision in national economy sector can only be obtained with excellent national economic data quality. Unfortunately, the collection process of true, accurate and complete national data is still expensive and time-consuming. Therefore, this study offers crowdsourcing as an alternative method towards the collection process of national data with low cost and dynamic. With case study basic commodity prices data collection nationwide, this method proved to empower the public as the owner of the data on self-reported commodities price in their region through an Android application, available for free on Google Play Store. This study was conducted for a year starting from January 2 to December 31, 2015. At the end of the study period, there were 7,442 people who have participated actively with an even distribution in all provinces in Indonesia. The amount of new user is 34 people per day with data entry is more than 400 data per day, and continues to increase.
\end{abstract}

Keywords: Android, crowdsourcing, data collection, national economic data

\section{Pendahuluan}

Data merupakan salah satu hal yang sangat menentukan dalam pengambilan suatu keputusan. Tanpa didukung data yang benar, akurat dan lengkap, keputusan yang diambil dapat menjadi salah sasaran dan tidak menyelesaikan permasalahan yang ada. Namun, pada kenyataannya, proses pengumpulan data yang benar, akurat dan lengkap tersebut masih mahal dan membutuhkan waktu lama. Sebagai contoh, proses pengumpulan data indikator perekonomian seperti harga komoditas pokok di tingkat eceran hampir selalu menggunakan metode survei lapangan yang mengharuskan petugas pengumpul data untuk turun langsung ke lokasi sumber data. Metode ini dapat menghasilkan data dengan tingkat akurasi tinggi, namun semakin luas lokasi survei diadakan dan semakin banyak data komoditas yang harus dikumpulkan, proses pengumpulan datanya juga menjadi semakin mahal dan lama. 
Untuk itu, diperlukan sebuah metode alternatif pengumpulan data harga komoditas pokok secara nasional yang berbiaya murah dan bersifat dinamis sesuai dengan harga di masyarakat yang fluktuatif. Salah satu metode alternatif yang potensial adalah crowdsourcing, suatu metode yang memberdayakan masyarakat sebagai pemilik data untuk melaporkan sendiri data harga komoditas di daerahnya.

Terdapat banyak definisi crowdsourcing, namun yang paling banyak dikutip adalah definisi dari Howe [1]. Menurut Howe, crowdsourcing merupakan suatu tindakan dalam melakukan sebuah pekerjaan yang tadinya dikerjakan secara tradisional oleh petugas/pegawai, lalu kemudian pekerjaan tersebut secara umum di-outsource-kan ke sekelompok orang banyak yang tidak dikenal [2].

Metode crowdsourcing ini telah banyak dipakai untuk pengumpulan data pada penelitianpenelitian yang terdahulu. Sebagai contoh, ketika terjadi gempa bumi di Haiti pada tahun 2010, Zook dkk menggunakan metode crowdsourcing untuk mengumpulkan data jalan di Haiti untuk keperluan tanggap darurat bencana. Sebelumnya, data jalan yang ada kurang dapat diandalkan sehingga menyulitkan petugas dan relawan dalam menentukan rute penyelamatan. Hasil penelitian menyimpulkan bahwa crowdsourcing memegang peranan penting dalam menyalurkan bantuan logistik bencana [3].

Contoh lain, Rai dkk melakukan pemetaan ruangan indoor di gedung perkantoran yang besar dengan menggunakan Radio Frequency fingerprinting berdasarkan wifi atau sinyal seluler. Metode crowdsourcing digunakan untuk menyediakan training data untuk proses kalibrasi tanpa campur tangan pengguna dengan memanfaatkan sensor-sensor inersia yang ada pada smartphone seperti accelerometer, kompas dan gyroscope. Kesimpulan penelitian tersebut adalah sistem crowdsourcing yang dibangun mampu memberikan hasil berupa lokasi indoor yang akurat [4].

Figliozzi menggunakan metode crowdsourcing di bidang transportasi untuk mengumpulkan data pengukuran performa sepeda dan juga identifikasi fasilitas-fasilitas umum yang membutuhkan perbaikan di Amerika Serikat. Penelitian tersebut menggunakan sebuah aplikasi mobile ORcycle, untuk mengumpulkan data pengguna sepeda, rute yang dilewati dan tingkat kenyamanan menggunakan sepeda di rute tersebut. ORcycle sendiri merupakan aplikasi mobile pertama yang disebar secara nasional untuk mengumpulkan data keamanan dan kecelakaan sepeda [5].

Penelitian lain yang juga masih di bidang transportasi dilakukan oleh Assemi. Assemi menggunakan metode crowdsourcing untuk melakukan pengumpulan revealed preference data dalam konteks studi transportasi di Australia. Penelitian tersebut menggunakan crowdsourcing platform Amazon Mechanical Turk, sebuah aplikasi mobile ATLAS II dan survei. Hasil dari penelitian menunjukkan bahwa crowdsourcing dapat digunakan sebagai metode yang efektif untuk pengumpulan data [6].

Dengan didukung hasil dari penelitian-penelitian terbaru di atas, menarik untuk mengetahui apakah metode crowdsourcing dapat menjadi suatu metode alternatif untuk mengumpulkan data nasional yang berbiaya murah dan bersifat dinamis. Pembahasan penelitian ini akan dimulai dari tahap perancangan sistem yang kemudian dilanjutkan dengan hasil implementasi dan pembahasannya, serta diakhiri dengan kesimpulan.

\section{Metodologi Penelitian}

\subsection{Perancangan Sistem}

Proses perancangan sistem diawali dengan menerjemahkan karakteristik crowdsourcing menjadi kerangka acuan sistem. Setelah kerangka acuan tersebut jadi, perancangan kemudian dilanjutkan dengan mendesign cara kerja sistem, menentukan platform yang akan digunakan untuk implementasi sistem, dan mendiskusikan fitur-fitur utama pada sistem. Sesuai definisi crowdsourcing oleh Howe, sistem yang dirancang tidak boleh menggunakan petugas/pegawai khusus untuk mengumpulkan data harga barang di tingkat eceran. Tugas pengumpulan data harga tersebut harus di-outsource-kan ke sekelompok orang banyak yang tidak dikenal, yang dalam hal ini adalah masyarakat umum.

Salah satu kunci keberhasilan crowdsourcing adalah adanya motivasi yang tinggi dari masyarakat untuk ikut berpartisipasi. Agar masyarakat termotivasi untuk melaporkan data harga barang di 
daerahnya masing-masing, sistem yang dirancang harus mampu memberikan keuntungan secara langsung bagi penggunanya. Keuntungan yang diperoleh pengguna ini tidak dalam bentuk uang (profit) karena dapat menyebabkan biaya pengumpulan data menjadi mahal, akan tetapi lebih kepada manfaat (benefit).

Dengan mempertimbangkan hal tersebut di atas, sistem yang diusulkan dalam penelitian ini adalah berupa sebuah aplikasi untuk mencatat pengeluaran sehari-hari. Masyarakat umum sebagai pengguna aplikasi akan mendapat manfaat langsung berupa adanya suatu aplikasi yang dapat digunakan secara gratis untuk mencatat pengeluaran mereka, yang pada akhirnya dapat menghemat pengeluaran mereka karena adanya pencatatan keuangan yang baik.

Cara kerja sistem yang dirancang disajikan dalam Gambar 1. Masyarakat (dalam hal ini pembeli) melakukan transaksi jual beli suatu barang dengan penjual. Pembeli sebagai pengguna aplikasi kemudian mencatat tanggal transaksi, nama dan harga barang yang dibeli ke dalam aplikasi, lalu aplikasi akan melakukan sinkronisasi data tersebut beserta dengan data lokasi transaksi ke server/cloud sistem melalui suatu web service yang telah disediakan. Data yang masuk ke server/cloud kemudian dianalisis dan ditampilkan sebagai laporan bagi pihak-pihak yang berkepentingan.

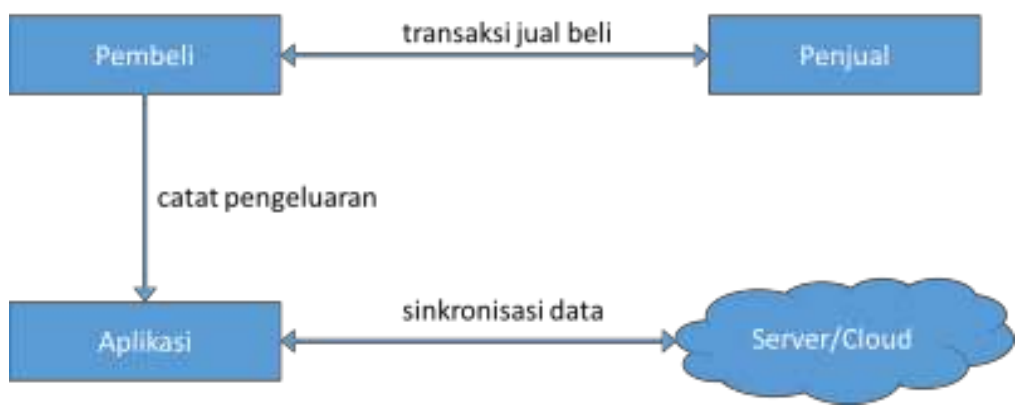

Gambar 1. Cara kerja sistem yang dirancang

Data yang diminta oleh aplikasi untuk diisi oleh pengguna dirancang agar seminimal mungkin, yaitu hanya tanggal transaksi, nama dan harga barang. Hal ini dimaksudkan agar pengguna aplikasi tidak merasa direpotkan dalam mengisi data, sehingga pengguna memiliki penilaian yang baik terhadap aplikasi dan terus menggunakan aplikasi. Setelah cara kerja sistem selesai dirancang, langkah yang dilakukan selanjutnya adalah menentukan platform yang akan digunakan untuk mengimplementasikan aplikasi. Syarat utama platform yang akan digunakan dirumuskan sebagai berikut.

a. Mampu menjangkau masyarakat umum dengan sebanyak-banyaknya untuk menjadi pengguna. Hal ini sesuai dengan prinsip crowdsourcing dimana jumlah pengguna aplikasi pada sistem akan sangat menentukan jumlah dan sebaran data yang didapat.

b. Mendukung untuk digunakan dalam kehidupan sehari-hari. Waktu terbaik untuk mencatat pengeluaran adalah segera setelah transaksi dilakukan. Masyarakat dapat melakukan transaksi jual beli barang kapan saja, dimana saja, sehingga platform yang digunakan juga harus mudah diakses kapan saja, dimana saja.

c. Dapat digunakan dengan ataupun tanpa koneksi internet. Proses pencatatan pengeluaran pada dasarnya bersifat independen terhadap ketersediaan internet, sehingga dengan koneksi internet yang bagaimanapun, proses tersebut harus tetap dapat dilakukan.

Setelah syarat utama platform yang akan digunakan berhasil dirumuskan, perancangan dilanjutkan dengan membandingkan platform-platform yang tersedia, yaitu desktop, mobile dan web. Ringkasan perbandingan ini disajikan dalam Tabel 1. Dari Tabel 1 tersebut tampak bahwa platform mobile dapat memenuhi semua persyaratan yang ada dengan cukup baik, sehingga penelitian ini akan menggunakan platform tersebut. 
Tabel 1. Perbandingan Platform yang Tersedia

\begin{tabular}{cccc}
\hline Syarat Platform & Desktop & Mobile & Web \\
\hline $\begin{array}{c}\text { Mampu menjangkau } \\
\text { masyarakat umum } \\
\text { dengan sebanyak- } \\
\text { banyaknya }\end{array}$ & $\begin{array}{c}\text { Dari 72 juta pengguna aktif media sosial di } \\
\text { Indonesia, 62 juta pengguna atau setara } \\
86,11 \% \text { menggunakan perangkat mobile [7] }\end{array}$ & $\begin{array}{c}\text { Dapat digunakan } \\
\text { pengguna desktop dan } \\
\text { mobile }\end{array}$ \\
$\begin{array}{c}\text { Mendukung untuk } \\
\text { digunakan dalam } \\
\text { kehidupan sehari-hari }\end{array}$ & $\begin{array}{c}\text { Sulit untuk diakses } \\
\text { kapanpun, dimanapun }\end{array}$ & Memenuhi syarat & $\begin{array}{c}\text { Memenuhi syarat, } \\
\text { sepanjang ada internet }\end{array}$ \\
$\begin{array}{c}\text { Dapat digunakan dengan } \\
\text { ataupun tanpa koneksi } \\
\text { internet }\end{array}$ & Memenuhi syarat & Memenuhi syarat & $\begin{array}{c}\text { Tidak memenuhi } \\
\text { syarat }\end{array}$ \\
\hline
\end{tabular}

Terdapat banyak jenis sistem operasi pada platform mobile dan terdapat banyak cara dalam mengembangkan aplikasi mobile. Untuk menjangkau semua sistem operasi yang ada, developer umumnya mengembangkan aplikasi berbasis web (web app) yang dibungkus menjadi aplikasi mobile seperti pada PhoneGap, Ionic dan sejenisnya. Namun, jika performa dan keamanan lebih penting, developer dapat mengembangkan aplikasi mobile yang bersifat native dan hanya dapat digunakan di sistem operasi tertentu, karena saat ini teknologi web app masih belum dapat menyamai performa yang dicapai oleh native app [8] dan web app pada umumnya juga kurang aman dibanding native app [9].

Oleh karena itu, pada penelitian ini, aplikasi yang akan dikembangkan berupa aplikasi native untuk sistem operasi Android. Pemilihan Android sebagai sistem operasi sasaran dikarenakan market share sistem operasi ini di Indonesia yang mencapai sekitar 74,2\% [10]. Versi Android minimal untuk menjalankan aplikasi yang dibangun adalah Gingerbread (API 10) agar aplikasi dapat menjangkau 99,9\% pengguna Android yang ada [11].

Setelah platform yang akan digunakan untuk mengimplementasikan aplikasi berhasil ditentukan, proses perancangan dilanjutkan dengan mendiskusikan fitur utama pada aplikasi. Fitur tersebut terdiri dari 3 hal yaitu: (1) proses pencatatan pengeluaran, (2) proses pengambilan data lokasi pengguna dan (3) proses sinkronisasi data pada perangkat pengguna dengan server/cloud sistem.

Proses pencatatan pengeluaran harus dirancang agar dapat dilakukan dengan mudah dan cepat. Oleh karena itu, selain data yang diinput pengguna harus dibuat seminimal mungkin, user interface yang digunakan juga harus user friendly. Sebagai contoh, input tanggal transaksi diset nilai default-nya sesuai tanggal pada hari pencatatan dan menggunakan DatePickerDialog seperti pada Gambar 2. Pengesetan nilai default tanggal transaksi tersebut dilakukan karena mayoritas pencatatan dilakukan pada hari yang sama dengan hari transaksi, atau pada hari sebelumnya. Penggunaan DatePickerDialog selain akan memudahkan pengguna memilih tanggal transaksi, juga untuk menghindari pengguna memasukkan tanggal yang tidak valid.

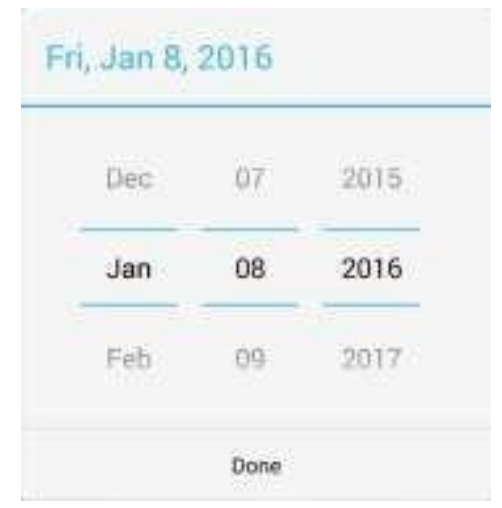

Gambar 2. DatePickerDialog untuk input tanggal transaksi 
Untuk input nama barang, aplikasi harus mengimplementasikan fitur auto-complete. Fitur ini selain berguna untuk memudahkan dan mempercepat proses pencatatan pengeluaran oleh pengguna, juga berfungsi untuk menjaga agar nama barang yang diinputkan pengguna lebih konsisten sehingga akan memudahkan saat proses analisis data harga barang. Ketika pengguna mulai memasukkan beberapa karakter nama barang, aplikasi akan melakukan query ke database lokal, dan menampilkan daftar nama barang yang cocok untuk dipilih oleh pengguna.

Untuk input harga barang, aplikasi akan menampilkan soft keyboard khusus yang hanya akan menampilkan angka dan karakter terkait angka seperti terlihat pada Gambar 3. Penggunaan soft keyboard khusus ini selain akan memudahkan pengguna dalam memasukkan data harga barang, juga untuk menghindari pengguna memasukkan data harga barang yang tidak valid.

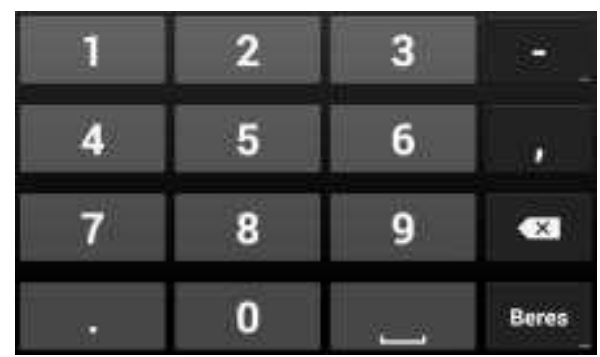

Gambar 3. Soft keyboard khusus untuk input harga barang

Terkait proses pengambilan data lokasi pengguna, sistem yang dibangun tidak memerlukan lokasi akurat pengguna seperti hasil penentuan posisi dengan GPS. Sistem hanya membutuhkan lokasi dengan keakuratan setingkat kota (coarse location), karena harga eceran barang dalam satu kota pada umumnya tidak berbeda jauh. Oleh karena itu, penentuan lokasi pengguna cukup menggunakan Cell-ID dan/atau $\mathrm{Wi}-\mathrm{Fi}$ dan dilakukan secara otomatis, tanpa campur tangan pengguna. Di sisi pengguna, penggunaan coarse location ini juga akan bermanfaat untuk melindungi privasi dan menghemat penggunaan baterai pada perangkat pengguna.

Terkait proses sinkronisasi data pada perangkat pengguna dengan server/cloud sistem, sesuai dengan syarat utama platform yang telah dibahas sebelumnya, aplikasi yang dibangun harus dapat dijalankan dengan ataupun tanpa koneksi internet. Untuk mengakomodir hal tersebut, data pengeluaran akan disimpan terlebih dahulu di database lokal aplikasi. Proses sinkronisasi kemudian akan dilakukan setiap periode waktu tertentu, hanya ketika koneksi internet tersedia. Setelah proses sinkronisasi selesai, data yang berhasil disinkronisasi ditandai agar tidak disinkronisasi lagi pada periode sinkronisasi selanjutnya.

Proses sinkronisasi data pada perangkat pengguna dengan server/cloud sistem ini dilakukan secara otomatis, tanpa campur tangan pengguna. Pengaturan default sinkronisasi adalah aktif, namun untuk menghormati privasi pengguna, pengguna dapat menonaktifkan proses sinkronisasi ini melalui menu Settings pada sistem operasi Android.

Dengan berakhirnya perancangan fitur-fitur utama aplikasi, berakhirlah tahapan perancangan sistem. Penelitian kemudian dilanjutkan dengan mengimplementasikan sistem yang telah dirancang.

\section{Hasil dan Pembahasan}

Sistem yang telah dirancang kemudian diimplementasikan. Terdapat dua bagian utama dari sistem, yaitu aplikasi Android yang akan dipasang di perangkat smartphone milik pengguna dan web service sebagai back-end untuk proses sinkronisasi yang akan dipasang di server/cloud. Implementasi aplikasi Android menggunakan Eclipse Kepler dan Android SDK dengan bahasa pemrograman Java dan database SQLite, sedangkan implementasi web service menggunakan bahasa pemrograman PHP dan database MySQL. Screenshot dari aplikasi Android pencatat pengeluaran yang telah diimplementasikan disajikan pada Gambar 4. Terhadap aplikasi yang telah dikembangkan tersebut kemudian dilakukan pengujian fungsionalitas untuk memastikan agar semua fitur yang ada pada aplikasi dapat berjalan sesuai dengan harapan. 


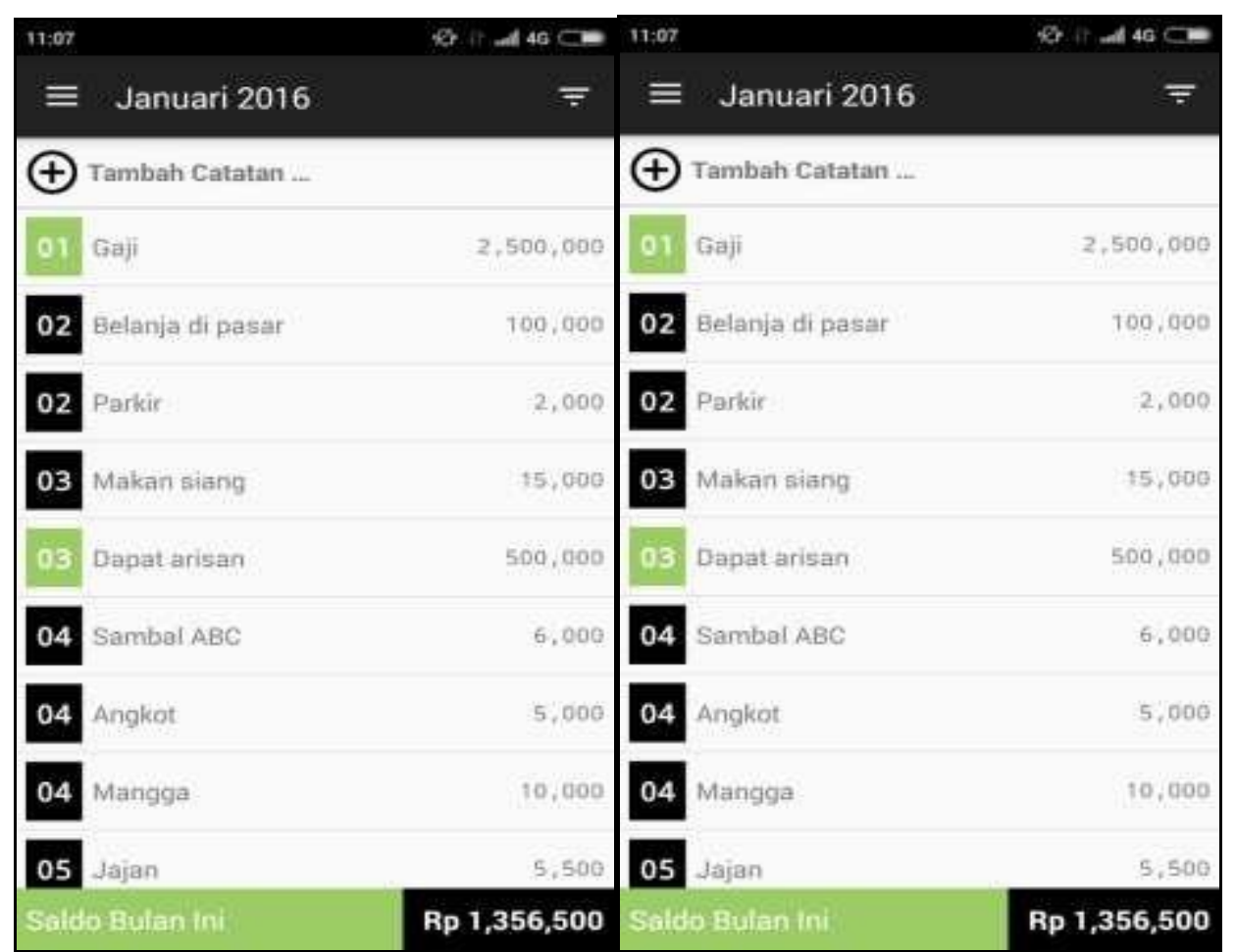

Gambar 4. Screenshot aplikasi yang telah dikembangkan

Aplikasi yang telah selesai diuji tersebut kemudian di-upload ke Google Play Store yang merupakan store aplikasi resmi dan paling populer untuk Android [12]. Proses upload dilakukan pada 2 Januari 2015 dan sejak saat itu, aplikasi pencatat pengeluaran ini telah dapat diakses dan digunakan oleh masyarakat umum sampai sekarang.

Penelitian ini tidak menggunakan media-media promosi tertentu untuk menarik calon pengguna agar memasang aplikasi ini pada perangkat mereka. Hal ini bertujuan untuk mengukur batas bawah tingkat keberhasilan aplikasi di masyarakat ketika effort dan biaya yang dikeluarkan seminimal mungkin. Dengan meningkatkan effort dan biaya promosi, hasil yang dicapai tentunya akan menjadi lebih baik lagi.

Untuk menilai apakah aplikasi yang dikembangkan telah berhasil sesuai harapan, terdapat kriteria-kriteria yang harus dipenuhi, diantaranya jumlah pengguna baru per hari, jumlah total pengguna, jumlah data masuk per hari ke dalam sistem dan distribusi pengguna secara nasional. Ketika jumlah data masuk per hari sudah cukup banyak dan terdistribusi secara merata di tingkat nasional, maka dapat dikatakan aplikasi yang dikembangkan telah berhasil diimplementasikan.

Di bulan pertama aplikasi di-publish di Google Play Store (Januari 2015), rata-rata pengguna baru per hari yang didapat sebesar 12,8 orang. Jumlah pengguna baru per hari sampai dengan bulan Agustus 2015 stabil di nilai rata-rata 14,7 orang, sebagaimana disajikan dalam Gambar 5 . Peningkatan jumlah pengguna yang cukup signifikan baru terjadi pada bulan September 2015 (meningkat 1,8x) dan bulan Oktober 2015 (meningkat 1,3x).

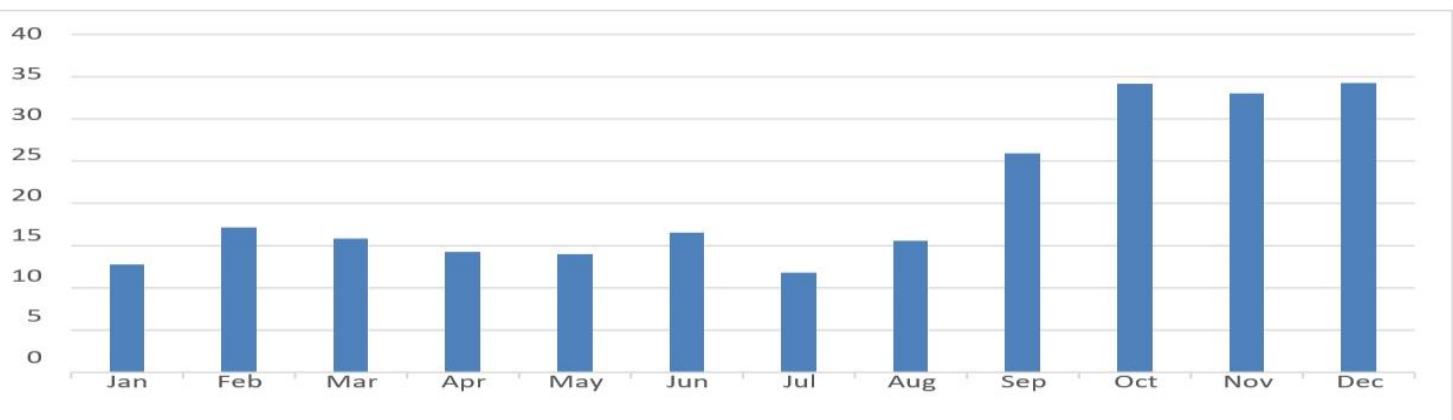

Gambar 5. Rata-rata pengguna baru per hari (2 Januari 2015 - 31 Desember 2015) 
Peningkatan pengguna baru per hari yang cukup signifikan yang terjadi pada bulan September dan Oktober 2015 tersebut erat kaitannya dengan semakin besarnya akumulasi total pengguna aplikasi yang dikembangkan, sebagaimana yang disajikan pada Gambar 6. Pada gambar tersebut tampak bahwa di akhir bulan September, jumlah pengguna mencapai 4.336 orang, dan di akhir bulan Oktober 2015, jumlah pengguna telah mencapai 5.395 orang.

Jumlah total pengguna yang cukup besar tersebut ternyata menyebabkan peningkatan peringkat aplikasi. Meski terdapat banyak faktor yang dapat mempengaruhi peringkat dari sebuah aplikasi di Google Play Store, jumlah total pengguna yang besar tersebut ternyata memiliki pengaruh yang signifikan. Peningkatan peringkat aplikasi ini kemudian diikuti dengan peningkatan keterlihatan aplikasi di mata calon pengguna, yang pada akhirnya mengarah kepada peningkatan jumlah pengguna baru per hari.

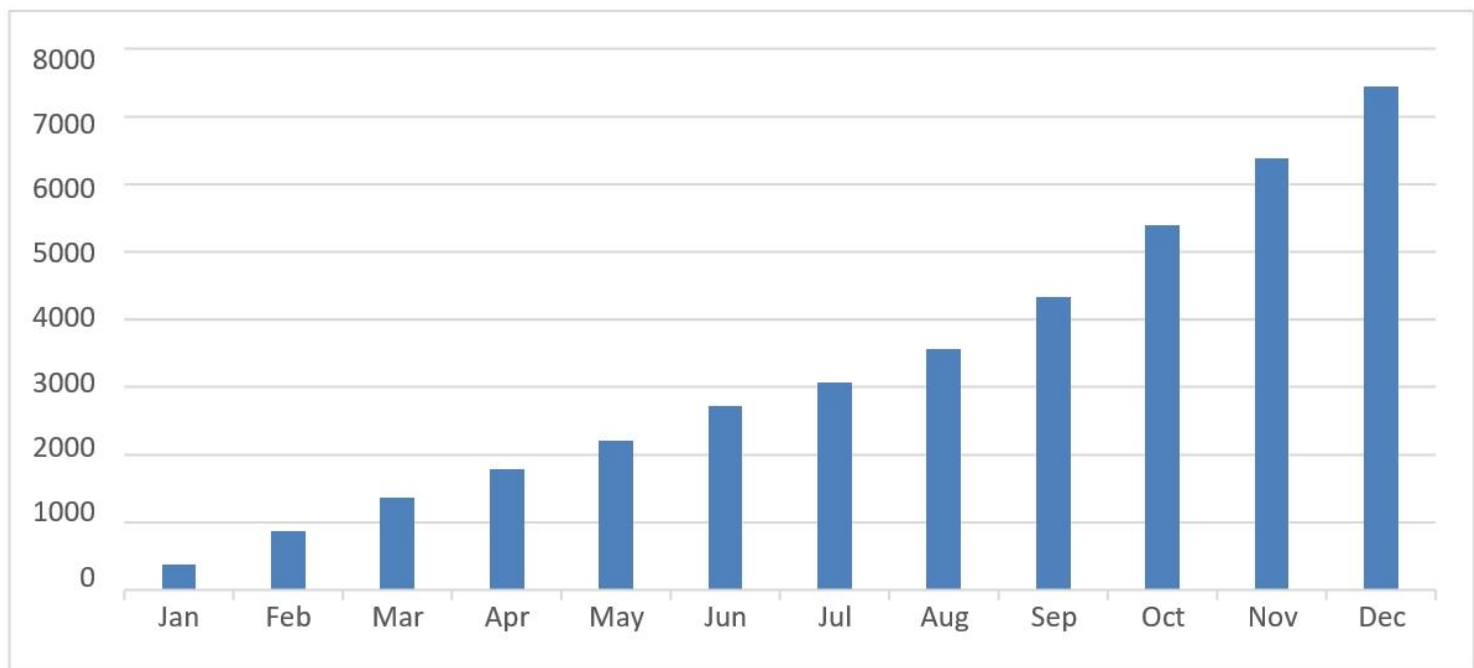

Gambar 6. Akumulasi total pengguna (2 Januari 2015 - 31 Desember 2015)

Sejalan dengan jumlah total pengguna yang terus meningkat, jumlah data yang masuk per hari ke dalam sistem juga memiliki tren yang positif dan terus mengalami peningkatan. Rata-rata jumlah data per hari yang masuk selama bulan Januari hingga Desember 2015 disajikan pada Gambar 7. Terlihat pada gambar, jumlah data per hari yang masuk pada bulan Desember mengalami peningkatan yang signifikan, hingga mencapai 2,7 kali bulan sebelumnya.

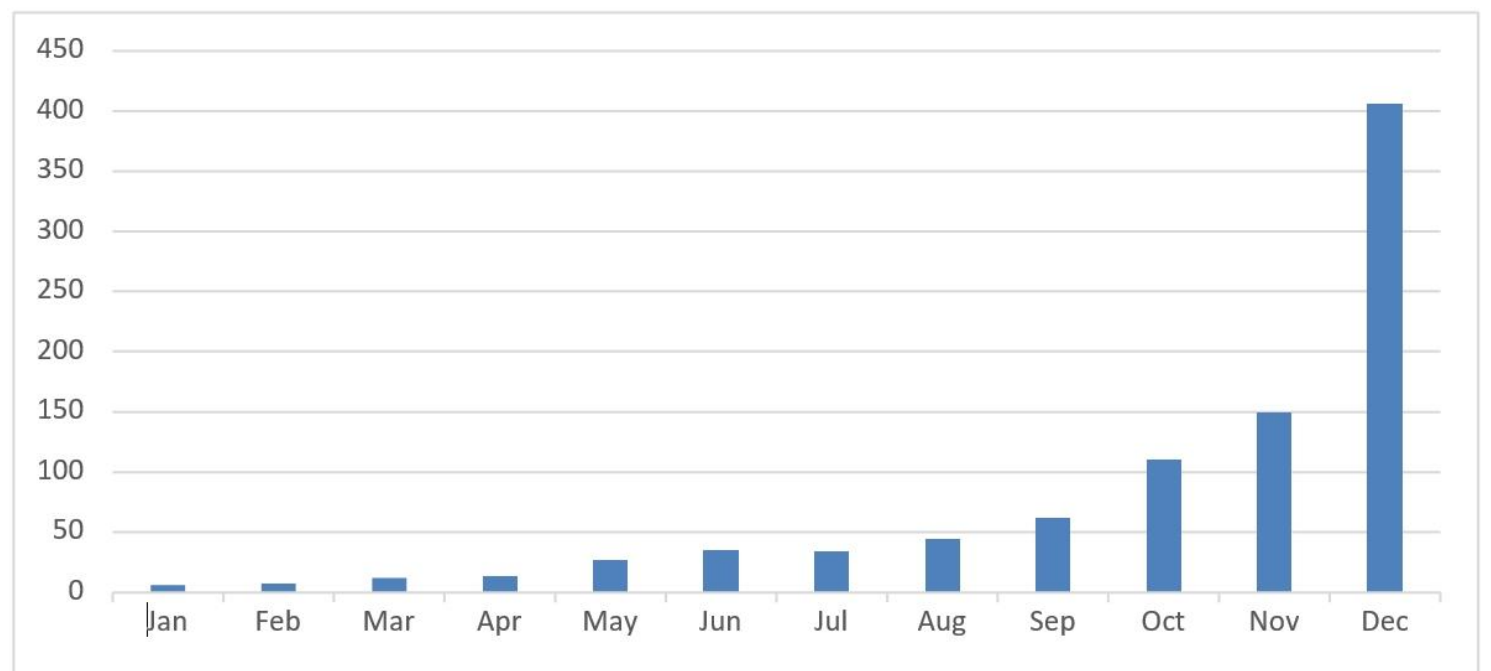

Gambar 7. Rata-rata data masuk per hari (2 Januari 2015 - 31 Desember 2015)

Jumlah data masuk per hari sepanjang bulan November dan Desember 2015 disajikan dalam Gambar 8. Tampak pada gambar bahwa jumlah data masuk per hari sepanjang bulan November stabil di angka $100-200$ data. Peningkatan jumlah data yang signifikan terjadi pada tanggal yang 
berdekatan dengan libur nasional, seperti Pilkada Serentak (9 Desember), Maulid Nabi Muhammad (24 Desember), Natal (25 Desember) dan Cuti Bersama Tahun Baru (31 Desember).

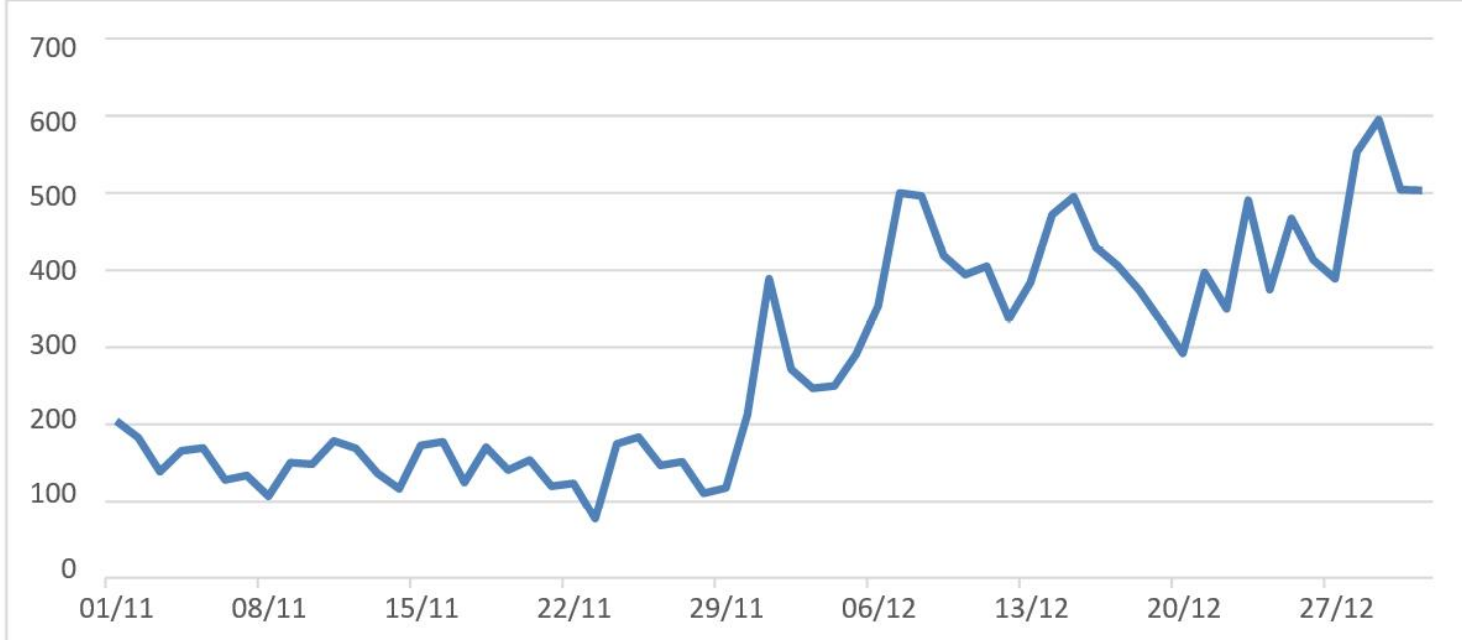

Gambar 8. Jumlah data masuk per hari (1 November 2015 - 31 Desember 2015)

Untuk mengetahui apakah pengguna aplikasi terdistribusi secara merata di tingkat nasional, persentase pengguna aplikasi dibandingkan dengan persentase penduduk di tiap propinsi di Indonesia. Data yang dibandingkan adalah distribusi penduduk Indonesia menurut propinsi tahun 2014 [13] dan distribusi pengguna aplikasi pada bulan Desember 2015. Perbandingan dilakukan dengan menggunakan rumus L2 relative error (L2re) seperti pada Persamaan (1). Persamaan tersebut digunakan untuk mengukur apakah data yang dibandingkan memiliki perbedaan yang signifikan atau tidak.

$$
L 2_{r e}=\sqrt{\frac{(\% p e n g g u n a-\% p e n d u d u k)^{2}}{\% \text { penduduk }}{ }^{2}}
$$

Hasil perbandingan persentase pengguna aplikasi dengan persentase penduduk di tiap propinsi di Indonesia disajikan dalam Tabel 2. Tabel tersebut menunjukkan bahwa pengguna aplikasi telah tersebar di seluruh propinsi di Indonesia secara proporsional, sesuai dengan persebaran penduduk, kecuali di dua propinsi (DKI Jakarta dan DI Yogyakarta) yang memiliki nilai L2re > 1,0 .

Tabel 2. Distribusi Pengguna Secara Nasional

\begin{tabular}{|c|c|c|c|c|}
\hline No. & Propinsi & $\%$ penduduk 2014 [13] & \% pengquna Des 2015 & L2re \\
\hline 1 & Aceh & 1,95 & 1,34 & 0,31 \\
\hline 2 & Sumatera Utara & 5,46 & 3,35 & 0,39 \\
\hline 3 & Sumatera Barat & 2,04 & 1,34 & 0,34 \\
\hline 4 & Riau & 2,45 & 1,87 & 0,24 \\
\hline 5 & Jambi & 1,33 & 1,07 & 0,19 \\
\hline 6 & Sumatera Selatan & 3,15 & 1,47 & 0,53 \\
\hline 7 & Bengkulu & 0,73 & 0,40 & 0,45 \\
\hline 8 & Lampung & 3,18 & 1,34 & 0,58 \\
\hline 9 & Kep. Bangka Belitung & 0,53 & 0,94 & 0,77 \\
\hline 10 & Kep. Riau & 0,76 & 0,94 & 0,23 \\
\hline 11 & DKI Jakarta & 4,00 & 15,66 & 2,92 \\
\hline 12 & Jawa Barat & 18,25 & 19,68 & 0,08 \\
\hline 13 & Jawa Tengah & 13,29 & 9,10 & 0,32 \\
\hline 14 & DI Yogyakarta & 1,44 & 3,61 & 1,51 \\
\hline
\end{tabular}




\begin{tabular}{llccc}
15 & Jawa Timur & 15,31 & 13,12 & 0,14 \\
16 & Banten & 4,64 & 7,23 & 0,56 \\
17 & Bali & 1,63 & 3,08 & 0,89 \\
18 & Nusa Tenggara Barat & 1,89 & 1,20 & 0,36 \\
19 & Nusa Tenggara Timur & 2,00 & 0,67 & 0,67 \\
20 & Kalimantan Barat & 1,87 & 0,94 & 0,50 \\
21 & Kalimantan Tengah & 0,97 & 0,54 & 0,45 \\
22 & Kalimantan Selatan & 1,56 & 0,94 & 0,40 \\
23 & Kalimantan Timur & 1,33 & 2,01 & 0,51 \\
24 & Kalimantan Utara & 0,25 & 0,13 & 0,46 \\
25 & Sulawesi Utara & 0,95 & 0,67 & 0,30 \\
26 & Sulawesi Tengah & 1,12 & 1,87 & 0,67 \\
27 & Sulawesi Selatan & 3,34 & 3,61 & 0,08 \\
28 & Sulawesi Tenggara & 0,97 & 0,54 & 0,45 \\
29 & Gorontalo & 0,44 & 0,27 & 0,39 \\
30 & Sulawesi Barat & 0,50 & 0,13 & 0,73 \\
31 & Maluku & 0,66 & 0,13 & 0,80 \\
32 & Maluku Utara & 0,45 & 0,13 & 0,70 \\
33 & Papua Barat & 0,34 & 0,27 & 0,21 \\
34 & Papua & 1,23 & 0,40 & 0,67 \\
\hline
\end{tabular}

Propinsi DKI Jakarta dan DI Yogyakarta yang memiliki nilai L2re di atas 1,00 kemungkinan disebabkan karena banyaknya pendatang yang tinggal di kedua propinsi-kota tersebut. Secara administrasi kependudukan (KTP), pengguna aplikasi di kedua propinsi tersebut bukan merupakan penduduk, namun karena mereka mencatat transaksi di kedua propinsi tersebut, maka pengguna aplikasi tersebut dianggap berasal dari propinsi DKI Jakarta dan DI Yogyakarta

\section{Kesimpulan}

Penelitian ini menawarkan metode crowdsourcing sebagai metode alternatif menuju proses pengumpulan data nasional yang berbiaya murah dan bersifat dinamis. Dengan studi kasus pengumpulan data harga komoditas pokok secara nasional, metode ini telah terbukti dapat memberdayakan masyarakat umum sebagai pemilik data untuk melaporkan sendiri data harga komoditas di daerahnya masing-masing melalui aplikasi Android yang disediakan secara gratis di Play Store.

Penelitian ini dilakukan selama setahun, mulai dari 2 Januari sampai dengan 31 Desember 2015. Di akhir masa penelitian, tercatat 7.442 orang telah berpartisipasi secara aktif dengan distribusi yang merata di seluruh propinsi di Indonesia, kecuali propinsi DKI Jakarta dan DI Yogyakarta. Jumlah pengguna baru mencapai 34 orang per hari dengan data masuk mencapai lebih dari 400 data per hari, dan terus meningkat. Dengan indikator-indikator kuantitatif tersebut, maka dapat dikatakan bahwa aplikasi berbasis crowdsourcing yang dikembangkan ini telah berhasil diimplementasikan ke masyarakat.

Penelitian selanjutnya akan membahas lebih detail proses ekstraksi data yang masuk ke dalam sistem secara real-time menjadi data harga komoditas pokok melalui data mining, mengukur indikator-indikator kualitatif dari data yang masuk dan mendiskusikan cara meningkatkan kualitas data masuk tersebut melalui suatu data quality management.

\section{Daftar Pustaka}

[1] E. Estellés-Arolas and L.-G. Fernando González, "Towards an integrated crowdsourcing definition," vol. 38, no. 2, pp. 189-200, 2012.

[2] J. Howe, How the power of the crowd is driving the future of business. 2008. 
[3] Z. Matthew, G. Mark, S. Taylor, and G. Sean, "Volunteered geographic information and crowdsourcing disaster relief: a case study of the Haitian earthquake," vol. 2, no. 2, pp. 7-33, 2010.

[4] A. Rai, K. K. Chintalapudi, V. N. Padmanabhan, and R. Sen, "Zee: Zero-Effort Crowdsourcing for Indoor Localization," in Proceedings of the 18th annual international conference on Mobile computing and networking - Mobicom '12, 2012, p. 293.

[5] M. Figliozzi and B. Bryan, "Evaluating the Use of Crowdsourcing as a Data Collection Method for Bicycle Performance Measures and Identification of Facility Improvement Needs," 2015.

[6] B. Assemi, D. Schlagwein, H. Safi, and M. Mesbah, "Crowdsourcing as a method for the collection of revealed preference data," Proc. - 9th IEEE Int. Symp. Serv. Syst. Eng. IEEE SOSE 2015, vol. 30, pp. 378-382, 2015.

[7] S. Kemp, "Digital, Social \& Mobile in 2015," We are social, no. January. pp. 1-375, 2015.

[8] K. Selvarajah, M. P. Craven, A. Massey, J. Crowe, K. Vedhara, and N. Raine-Fenning, "Native apps versus web apps: Which is best for healthcare applications?," Lect. Notes Comput. Sci. (including Subser. Lect. Notes Artif. Intell. Lect. Notes Bioinformatics), vol. 8005 LNCS, no. PART 2, pp. 189-196, 2013.

[9] A. Charland and B. Leroux, "mobile application Development: Web vs . native," Commun. ACM, vol. 54, pp. 0-5, 2011.

[10] Statista Inc., "Market share held by mobile operating systems in Indonesia from January 2012 to July 2015." 2015.

[11] Android-Developers, "Platform Versions." 2012.

[12] A. Tongaonkar, S. Dai, A. Nucci, and D. Song, Understanding mobile app usage patterns using in-app advertisements, vol. 7799 LNCS. 2013.

[13] D. Persentase, "Distribusi Persentase Penduduk menurut Provinsi, 2000-2014." p. 2035, 2014. 